\title{
T-Lymphocyte Activation Antigen CD80
}

National Cancer Institute

\section{Source}

National Cancer Institute. T-Lymphocyte Activation Antigen CD80. NCI Thesaurus. Code C15173.

T-lymphocyte activation antigen CD80 (288 aa, $33 \mathrm{kDa}$ ) is encoded by the human CD80 gene. This protein is involved in the regulation of $\mathrm{T}$-cell activation. 